\title{
PENGUATAN AKSESIBILITAS PEREMPUAN TERHADAP MODAL EKONOMI DI SUBAK GUAMA, TABANAN-BALI
}

\author{
Strengthening Women Accessibility \\ Towards Economic Capital In Subak Guama, \\ Tabanan-Bali
}

\section{Ni Wayan Sri Astiti*) \\ I Dewa Gede Raka Sarjana}

\author{
Fakultas Pertanian Univeritas Udayana, Bali, Indonesia \\ Email: sri_astiti@unud.ac.id*)
}

\begin{abstract}
This study discusses the participation of women in the management of the economic capital of Subak Guama, Marga District, Tabanan-Bali. The problem encountered was how is women's access to economic capital management (Kridit Usaha Mandiri / KUM) in Subak Guama. The purpose of this study is to find out: women's access to KUM economic capital in Subak Guama, and the level of women's income in managing KUM economic capital in the subak Guama, and their contribution to household income. Data was collected through a process of observation, document study, and in-depth interviews and structured interviews with 30 female farmers who participated in the management of KUM in Subak Guama. Data analysis uses descriptive-interpretative, qualitative and quantitative analysis. The results showed that women's access to KUM economic capital in the Guama subak only reached $20 \%$ of the total KUM lending of 256 people. Businesses developed by women farmers in Subak Guama include vegetable trading, upakara means trading, rice farming, tailoring, animal feed traders, pig satay traders, jaje begina production, production of various wet and fried cakes, food stalls and Chicken Betutu production and oyster mushrooms with an average loan of Rp 6,963,000. While the average income of the business developed reached $R p$ 67,745,285.25 per year, with total household income of Rp 125,615,276.5 per year. Thus the contribution of women to household income reached $53.93 \%$.
\end{abstract}

Keywords: Accessibility, Women, KUM, Subak Guama

\section{ABSTRAK}

Kajian ini membahas tentang partisipasi perempuan dalam pengelolaan modal ekonomi Subak Guama, Kecamatan Marga, Tabanan-Bali. Permasalahan yang ditemui adalah bagaimanakah akses perempuan dalam pengelolaan modal ekonomi (Kredit Usaha Mandiri/KUM) di Subak 
Guama. Tujuan dari kajian ini adalah untuk mengetahui akses perempuan terhadap modal Ekonomi KUM di Subak Guama, dan tingkat pendapatan perempuan dalam mengelola modal ekonomi KUM di subak Guama, serta kontribusinya terhadap pendapatan rumahtangga. Data dikumpulkan melalui proses observasi, studi dokumen, dan wawancara mendalam dan wawancara terstruktur dengan 30 orang petani perempuan yang berpartisipasi dalam pengelolaan KUM di Subak Guama. Analisis data menggunakan analiss deskriptif-intepretatif, kualitatif dan kuantitatip. Hasil penelitian menunjukan bahwa akses perempuan terhadap modal ekonomi KUM di subak Guama hanya mencapai 20\% dari total peminjan KUM 256 orang. Usaha yang dkembangkan oleh petani perempuan di Subak Guama meliputi usaha dagang sayur mayur, dagang sarana upakara, usahatani padi, tukang jahit, pedagang pakan ternak, pedagang sate babi, produksi jaje begina, produksi aneka kue basah dan gorengan , warung makan dan produksi Betutu Ayam dan jamur tiram dengan rataan pinjaman kredit adalah Rp 6.963.000,-. Sedangkan rataan pendapatan dari usaha yang dikembangkan mencapai Rp 67,745,285.25,- per tahun, dengan total pendapatan rumahtangga sebesar Rp 125,615,276.5 per tahun. Dengan demikian kontribusi perempuan terhadap penadapat rumahtangga mencapai $53,93 \%$.

Kata Kunci: Aksesbilitas, Perempuan, KUM, Subak Guama

\section{PENDAHLUAN}

\section{Latar Belakang}

Dalam konteks politik, sosial-budaya, dan ekonomi posisi kaum perempuan Indonesia masih cenderung lebih lemah dibandingkan kaum laki-laki. Untuk itu, pemberdayaan perempuan demi peningkatan kualitas kesejahteraan keluarga, masyarakat dan bangsa perlu terus diperjuangkan. Pemberdayaan perempuan direkomendasikan penting dalam kongres Internasional Kependudukan dan Pembangunan (ICPD) tahun 1994 di Kairo. Inti strategi pemberdayaan (empowerment) ini bukan sekadar menjadikan kaum perempuan setara dengan kaun laki-laki, tetapi juga demi peningkatan kapasitas, kualitas, kemandirian dan kekuatan internal mereka untuk memperoleh hak dalam menentukan pilihan kehidupannya.

Perjuangan perempuan Bali dalam meraih keadilan gender bergerak dinamis. Keadilan gender terkait dengan konsep kemitrasejajaran dalam GBHN (1993) bahwa pembinaan peranan perempuan sebagai mitra sejajar laki-laki ditujukan untuk meningkatkan peran aktif dalam kegiatan pembangunan, termasuk upaya mewujudkan keluarga sehat, sejahtera, dan bahagia. Selanjutnya dalam Millinium Developmen Goals (MDGS) point 3 diharapkan adanya peningkatan derajat hidup kaum perempuan.

Berkaitan dengan hal tersebut lembaga tradisional subak di Bali juga memberikan peluang pada perempuan untuk memanfaatkan kredit yang dikelola oleh subak secara mandiri. Salah satu subak yang mengelola kredit untuk meningkatkan kesejantreaan anggota subaknya adalah Subak Guama di Kecamatan Marga, Tabanan-Bali. Pada tahun 2002 pemerintah melalui 
Departemen Pertanian membuat kebijakan untuk meningkatkan produksi padi sawah melalui Peningkatan Produktivitas Padi Terpadu (P3T). Strategi yang ditempuh dalam kegiatan P3T adalah mensinergiskan antara komponen teknologi dengan lingkungan biofisik dalam satu paket dengan memperhatikan kondisi sosial ekonomi petani setempat. Kegiatan P3T ini dikembangkan melalui pendekatan Intergrated Crop Management (ICM) atau Pengelolaan Tanaman Terpadu (PTT), Crops Livestock System (CLS) atau Sistem Integrasi Padi-Ternak (SIPT) dan Kredit Usaha Mandiri (KUM). Kredit KUM khusus diperuntukkan untuk petani perempuan. Namun dalam pengalokasian dana BPLM ini perempuan memperoleh akses yang lebih rendah ika dibandingkan dengan petani laki-laki. Perlu dikaji bagaimana aksse perempuan terhadap kredit KUM yang dikelola oleh Subak Guama.

\section{Tujuan Penelitian}

Tujuan dari kajian ini adalah untuk mengetahui hal sebagai berikut:

1. Mengetahui Akses perempuan dalam mendapatkan modal ekonomi (KUM) di Subak Guama.

2. Mengetahui Pendapatan perempuan dalam mengelola modal ekonomi (KUM) di Subak Guama.

\section{METODOLOGI PENELITIAN}

\section{Lokasi Penelitian}

Penelitian ini dilakukan di Subak Guama Kecamatan Marga, Kabupaten Tabanan Bali. Lokasi Penelitian ditetapkam secara purposive (sengaja), dengan berbagai pertimbangan. Pertimbangan penetapan lokasi penelitian antara lain.

1. Subak Guama adalah subak yang sudah maju dan termasuk subak yang modern sehingga sangat respon terhadap segala informasi yang ditawarkan pada Subak.

2. Subak Guama memiliki suatu unit kelembagaan petani yang berwawasan agribisnis yaitu Koperasi Usaha Agribisnis Terpadu (KUAT).

3. Subak Guama dipergunakan sebagai wadah untuk transfer inovasi yang dilakuakn oleh BPTP Bali.

\section{Metode Pngumpulan Data}

Pengumpulan data dilakukan dengan beberapa teknik yaitu; (a) Wawancara terstruktu, (b) Wawancara Mendalam, dilakukan pada key informan dengan mempergunakan pedoman wawancara, (c) Dokumentasi, yaitu metode pengumpulan data dengan melihat atau menganalisis dokumen-dokumen yang dibuat oleh obyek sendiri atau oleh orang lain tentang obyek. 


\section{Analisis Data}

Analaisis data yang dipergunakan untuk menjawab rumusan masalah atau mencapai tujuan dalam penelitian ini adalah :

1. Untuk menjawab tujuan satu dengan mempergunakan adalisis deskriptif kualitatif dan kuantitatif. Dalam hal ini akan dilihat dari kesempatan perempuan untuk mendapatkan KUM. Akan dilihat pula cara mengelolaan KUM oleh petani perempuan di Subak Guama.

2. Untuk menjawab tujuan dua dengan analisis pendapatan pada penelitian ini menganalisis pendapatan atas biaya tunai dan biaya total pada usaha yang dilakukan. Persamaan pendapatan usahatani dinyatakan dalam rumus sebagai berikut.

$$
\sum_{i=2}^{i=2} P 1=\sum T R-\sum T C
$$

Keterangan :

$$
\begin{aligned}
& \mathrm{i}=1=\text { tunai } \\
& \mathrm{ii}=2=\text { tidak tunai } \\
& \mathrm{P}=\text { Pendapatan }(\mathrm{Rp}) \\
& \mathrm{TR}=\text { Total penerimaan }(\mathrm{Rp}) \\
& \mathrm{TC}=\text { Total biaya }(\mathrm{Rp})
\end{aligned}
$$

Penerimaan usahatani merupakan perkalian antara jumlah produksi dengan harga jual (Soekartawi, 1995). Rumus penerimaan sebagai berikut.

$$
\mathbf{T R}=\mathbf{P} \times \mathbf{Q}
$$

Keterangan:

TR $=$ Total penerimaan $(\mathrm{Rp})$

$\mathrm{Q}=$ Produksi yang diperoleh dalam suatu usahatani $(\mathrm{kg})$

$\mathrm{P}=$ Harga jual produksi per unit $(\mathrm{Rp} / \mathrm{kg})$

Biaya total usahatani merupakan penjumlahan biaya variabel dan biaya tetap (Soekartawi, 1995). Rumus biaya total sebagai berikut.

$$
\sum_{i=1}^{n} T C=\sum T V C+\sum T F C
$$

Keterangan:

$\mathrm{TC}=$ Total biaya $(\mathrm{Rp})$

$\mathrm{TVC}=$ Total biaya variabel $(\mathrm{Rp})$

TFC $=$ Total biaya tetap $(\mathrm{Rp})$ 


\section{HASIL DAN DAN PEMBAHASAN}

\section{Pengembangan Unit Ekonomi (KUAT) Di Subak Guama}

Subak Guama merupakan subak yang modern dan sangat adaftif terhadap inovasi. Subak Guama dalam menunjang program pembangunan pertanian secara umum, telah mengembangkan unit ekonomi untuk memperkuat permodalam dalam subak. Disamping itu Subak Guama juga dijadikan sebagai media untuk melakukan desiminasi hasil hasil penelitian dari pemerintah melalui Balai Pengkajian Teknologi Pertanian Bali. Subak Guama telah mendirikan KUAT (Koperasi Usaha Agribisnis Terpadu ) dengan mengembangkan berbagai fasilitas kredit.

Koperasi Usaha Agribisnis Terpadu (KUAT) Subak Guama didirikan pada tanggal 1 April 2002 atas dasar kebersamaan untuk tumbuh dan berkembang sebagai organisasi lokal tradisional dan memiliki basis ekonomi dan telah berbadan hukum Koperasi Nomor 22/BH/ DISKOP/VIII/003 Tanggal 14 Agustus 2003. Pembentukan KUAT ini memiliki fungsi untuk mengadakan pengelolaan unit-unit usaha ekonomi bagi anggota Subak Guama. KUAT merupakan suatu unit lembaga yang tidak dapat terpisahkan dan saling bersinergi dengan lembaga subak yang ada, karena KUAT ini menjadi lembaga pengelola asset subak yang bersumber dari modal eksternal sebagai suatu upaya untuk memberdayakan subak dan anggotanya terutama di dalam aspek pelayanan usahatani guna meningkatkan kesejahteraan para petani anggotanya. Sumber modal KUAT Subak Guama ini adalah BPLM (Bantuan Pinjaman Langsung Masyarakat) dari Bagian Proyek Pengembangan Padi Terpadu Bali, pada Tahun Anggaran 2002 sebesar Rp 843.2000.000,00 untuk berbagai kegiatan dengan nilai dari masing-masing kegiatan adalah sebagai berikut:

1. Kegiatan Pengelolaan Padi Terpadu (Integradted Crops Management) ICM sebesar Rp.98.000.000,00

2. Kegiatan Kegiatan Integrasi Padi-Ternak (Crops-Livestock System) sebesar Rp. $663.500 .000,00$

3. Kegiatan penguatan modal usaha rumah tangga yaitu Kredit Usaha Mandiri (KUM) sebesar Rp. 81.700.000,00.

Secara lebih rinci beberapa kegiatan tersebut di atas meliputi berbagai usaha yang dilakukan dalam KUAT Subak Guama, di antaranya adalah sebagai berikut:

Jenis Kegiatan Pokok KUAT Subak Guama ( BLM Th. 2002 ) yaitu :

1. PTT/ICM (Pengembangan Tanaman Terpadu/Integreted Corps Management)

Pengolahan tanaman terpadu yang direalisaikan dalam bentuk penyaluran saprodi (sarana produksi padi) dari penyaluran benih, pupuk, dan pestisida yang diterima oleh anggota Subak Guama dalam bentuk saprodi berupa benih, pupuk dan pestisida dengan sistem pembayaran panen (4 bulan) dan bunga 1\%/bulan.

2. ISPT/CLS (Integrasi Sistem Padi Ternak/Corps Livestock System)

Pengembangan integrasi padi dengan ternak yang direalisasikan dalam bentuk kredit ternak sapi kepada anggota Subak Guama dengan plapon kredit sebesar Rp. 3.000.000,00/ekor dengan bunga $1 \%$ menetap per bulan dengan jangka waktu pengembalian selama dua tahun. 
3. KUM (Kredit Usaha Mandiri/Simpan Pinjam)

Pemberian bantuan penguatan modal usaha untuk para wanita tani diantaranya, usaha minyak kelapa, usaha ternak babi, usaha jajan bali, usaha tenun, usaha ukir dan usaha dagang.

Adapun pengembangan usaha yang dilakukan KUAT Subak Guama selain kegiatan pokok BLM sebagai berikut.

1. Usaha Penangkaran Benih Padi

Dalam proses penangkaran ini KUAT subak guama baru bisa menangkarkan 10-20 ha/musim dengan kapasitas produksi mencapai kurang lebih 100 ton/musim tanam.

2. Usaha Prosesing Kompos/PPO

Usaha prosesing pupuk organik adalah menggunakan bahan baku ternak sapi yang sebagian besar diambil dari kelompok tani di Subak Guama dengan menggunakan bahan aktif Romino Bacillus (RB) yang merupakan binaan dari BPTP. Produksi pupuk organik subak guama mencapai rata rata 25 ton/bulan dan sebagian besar dipasrkan untuk komoditi tanaman hias dan hortikultura.

3. UPJA (Unit Pelayanan Jasa Alat \& Mesin Pertanian)

Unit pelayanan jasa alat dan mesin pertanian adalah untuk menunjang kegiatan dalam usaha meningkatkan produksi pertanian yang dilakukan pada waktu pasca tanam hingga penanganan pasca panen. Alat dan mesin yang tersedia antara lain : hand traktor, seeder ( alat tanam tabela ), power tresser, RMU ( Rice Milling Unit ).

Tahun 2007 KUAT Subak Guama melaksanakan program nasional yaitu Prima Tani (Program Rintisan dan Akselerasi Pemasyarakatan Inovasi Teknologi Pertanian). Adapun kegiatan kegiatan yang dilakukan dalam Prima Tani ini adalah sebagai berikut.

1. Bidang penerapan teknologi pola tanam ( tanaman pangan \& palawija )

2. Pengolahan limbah ternak untuk pupuk organik padat \& cair

3. Usaha penangkaran benih tanaman padi bersertifikat

4. Pengenalan beberapa varietas unggul baru

5. Usaha pengeringan dan prosesing (Rice Milling Unit)

6. Pengadaan kandang koloni (usaha penggemukan sapi )

7. Penguatan kelembagaan kelompok / wanita tani

8. Pembentukan jaringan kerja sama lintas instansi

9. Peningkatan kesehatan ternak

10. Pelatihan SLPHT, pasca panen, dan klinik konsultasi pertanian

Susunan struktur organisasi Koperasi Usaha Agribisnis Terpadu (KUAT) Subak Guama terdiri atas Ketua yang dikoordinir oleh Badan Pembina dan Pelindung (BPP) serta Badan Pengawas, Sekretaris, Bendahara, seksi/unit ternak/CLS, seksi/unit saprodi (ICM), seksi/unit simpan pinjam (KUM), seksi/unit pelayanan jasa alsintan (UPJA), kelian tempek dan anggota subak. Subak Guama dan KUAT saling bersinergi dan berkaitan karena struktur organisasi Subak Guama merupakan bagian dari struktur organisasi KUAT, diantaranya ketua (pekaseh), sekretaris (penyarikan) dan bendahara (petengen), ketua/kelian tempek dan anggota subak. KUAT Subak Guama merupakan suatu lembaga pertanian yang dibentuk untuk membina keahlian dan keterampilan para anggota serta mengajak anggota untuk tetap bersemangat 
memproduksi benih padi bersertifikat secara tepat, memantau harga benih padi di pasaran, memfasilitasi dan menyediakan sarana dan prasarana yang dapat membantu produktivitas petani dalam melakukan usahanya. Struktur organisasi KUAT Subak Guama Subak Guama disajikan pada Gambar 1.

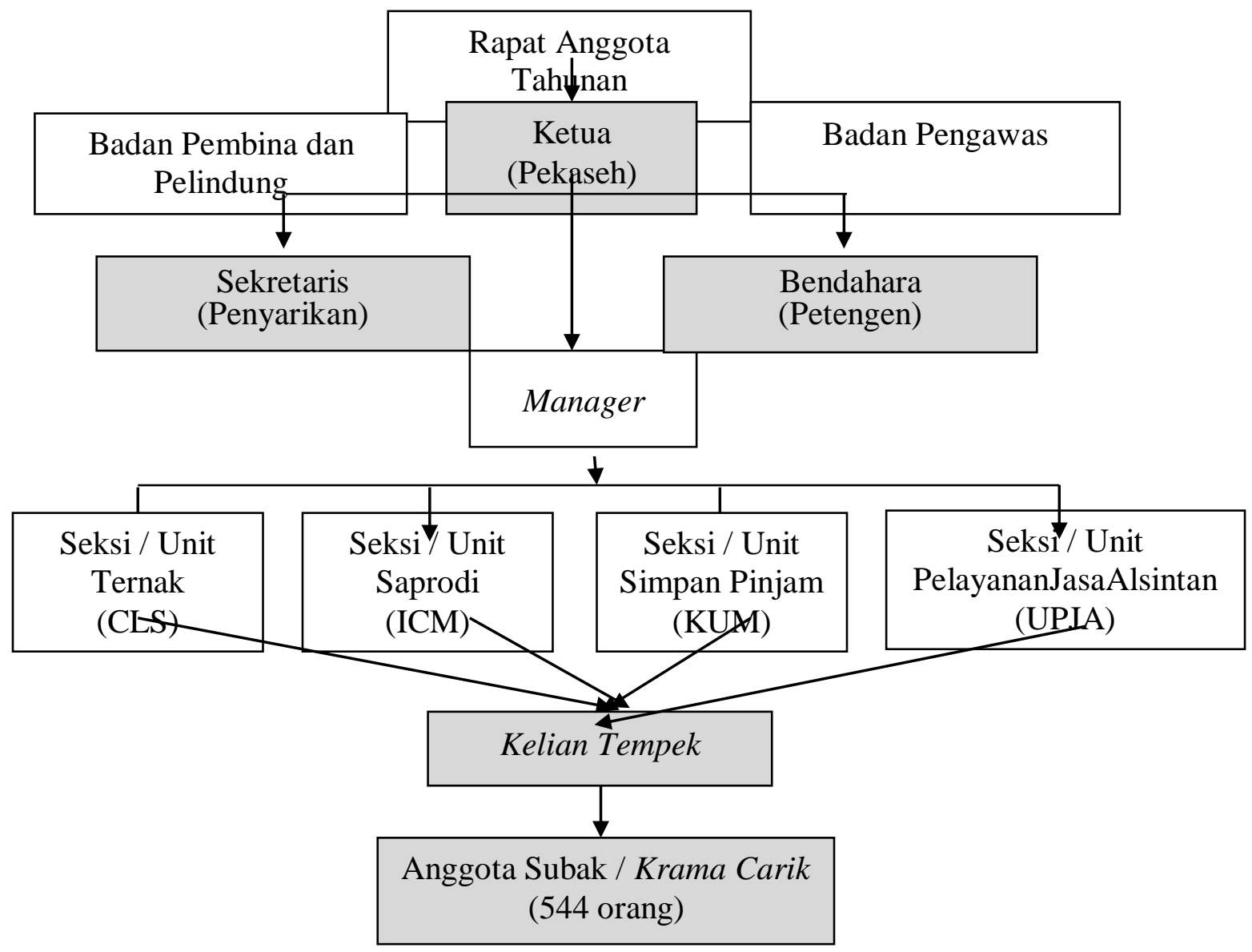

Gambar 1

Struktur Organisasi Koperasi Usaha Agribisnis Terpadu (KUAT) Subak Guama Sumber: Manager Koperasi Usaha Agribisnis Terpadu (KUAT) Subak Guama (2018) Keterangan:

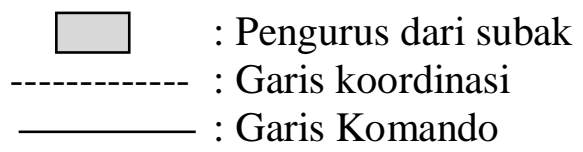




\section{Keterkaiatan Antara Karakteristik Responden dengan Usaha yang Digeluti}

Kegiatan usaha yang dikembangkan oleh petani perempuan di Subak Guama meliptui 1) kegiatan usaha dagang sayuran dan lauk pauk dengan proporsi sebesar 33\% dari keseluruhan pelaku usaha yang ada; 2) usaha dagang banten alat upacara "canang sari", "bebanten" dan "orti" dengan jumlah sebesar $17 \%$; 3) sebagai petani yang melakukan kegiatan usahatani sebesar $17 \%$; dan 4) kegiatan usaha pembuatan jaja begina sebesar 13\%, 5) usaha lai-lain sebesar $18 \%$.

Jika ditinjau dari segi pekerjaannya tampaknya jenis ini disenangi oleh kaum perempuan yaitu pekerjaan sebagai pedagang yang sangat mudah untuk dilakukan Disini dapat dilihat bahwa besarnya tanggungan keluarga (rata-rata 4,03 orang/KK) menunjukkan bahwa faktor beban keluarga menjadi alasan utama untuk mempunyai pekerjaan utama dan juga pekerjaan sampingan. Di samping karena tingkat pendidikan yang relatif tinggi (rata-rata 10,7 tahun atau setara dengan SMA) sangat mendorong untuk membuat usaha sendiri supaya bisa meningkatkan pendapatan rumahtangganya. Melakukan usaha sebagai pedagang merupakan pilihan terbaik bagi ibu rumah tangga dalam menambah pendapatan rumahtangganya tanpa harus bekerja diluar rumah.

Berikut disajikan karakteristik responden secara keseluruhan yang meliputi umur, pendidikan dan jumlah tanggungan dirinci menurut jenis usaha industry, tertera pada Tabel 1

Tabel 1. Keterkaitan antara Jenis Usaha, Umur, Pendidikkan Dan Beban Tanggungan Keluarga

\begin{tabular}{|c|c|c|c|c|c|c|c|}
\hline \multirow[t]{2}{*}{ No } & \multirow[t]{2}{*}{ Jenis usaha } & \multirow{2}{*}{$\begin{array}{c}\text { Jumla } \\
\text { h } \\
(\%)\end{array}$} & \multicolumn{3}{|c|}{ Umur (th) } & \multirow{2}{*}{$\begin{array}{l}\text { Rataan } \\
\text { pendidikka } \\
\text { n (Th) }\end{array}$} & \multirow{2}{*}{$\begin{array}{l}\text { Beban } \\
\text { tanggung } \\
\text { an } \\
\text { keluarga }\end{array}$} \\
\hline & & & & $\begin{array}{l}\text { tang } \\
\text { nur }\end{array}$ & rataan & & \\
\hline 1 & $\begin{array}{l}\text { Dagang Sayur Mayur, Lauk } \\
\text { Pauk dan Rujak, Pakan } \\
\text { Ternak, sate babi, sarana } \\
\text { upakara (17) }\end{array}$ & 57 & 29 & 56 & 41.71 & 11,11 & 3.8 \\
\hline 2 & Usaha Tani Padi (5) & 17 & 44 & 69 & 53,2 & 7,2 & 4,4 \\
\hline 3 & Tukang Jahit (1) & 3 & 47 & 47 & 47 & 12 & 4 \\
\hline 4 & $\begin{array}{l}\text { Wirausaha (Usaha Jaje } \\
\text { begina, aneka kue basah dan } \\
\text { gorengan, betutu Ayam, } \\
\text { warung makan) } \\
\text { ( } 7 \text { ) }\end{array}$ & 23 & 37 & 51 & 42,57 & 12 & 4,2 \\
\hline & Total/rataan & 100 & & & 44,6 & 10,7 & 4.03 \\
\hline
\end{tabular}




\section{Usaha dagang}

Usaha yang dominan digeluti adalah usaha dagang hingga menpapai $57 \%$ yang meliputi, dagang sayur mayur, lauk pauk, dan rujak, pakan ternak, sate babi dan saran upakara hingga mencapai. Pekerjaan ini dilakukan oleh perempuan sesuai dengan peran perempuan sebagai ibu rumahtangga yang sebagian besar mengerjakan pekerjaan domestik. Rata- rata besarnya modal pinjaaman untuk usaha dagang ini adalah Rp. 4.658.235,- yang sepenuhnya mempergunakan dana kriditan dari KUM Subak Guama,dengan bunga pinjamnan sebesar dua persen yang dikredit 10 kali. Sebagian besar usaha dagang yang dilakukan adalah sebagai dagang sayuran, petani secara langsung bisa mejual hasil usahataninya dan juga petani perempuan ini membeli sayuan di pasar dan kemudian dijual lagi dipasar maupun di ruamhnya. Sedangkan yang menjual sarana upakara atau banten ini sepenuhnya kegiatan dilakukan dirmahnya sendiri. Hanya bahan baku berupa janur, kelapa, telor, jajan, buah dan bunga bungaan di beli di pasar. Sarana upakara/banten yang dijual berupa canang, ceper, wakul daksina, tamas, porosan dan sarana banten yang sudah siap untuk dipergunakan. Petani perempuan ini selain berdagang juga ikut melakukan kegiatan usahatani di sawahnya. Petani perempuan hanya berjualan sampai siang hari kemudian selanjutan mengerjakan pekerjaan domestic lainnya.

Rata-rata umur petani yang profesinya sebagai pedagang adalah 41,71 tahun dengan kisaan umur 25-59 tahun yang masih tergolong produktif dengan lama pendidikkakan rata rata 11,11 tahun yang setingkat dengan SMA yang berarti pendidikkannya tergolong sedang. Rataan tangguangan atau beban keluarganya sebesar 3,8 orang, hal ini menyebabkan petani perempuan harus memiliki usaha sampingan selain selain sebagai petani yaitu untuk membantu menambah pendapatan rumahtangganya (Tabel 1).

\section{Usaha tani}

Hanya sebagian kecil petani perempuan (17\%) mengembangkan usahatani. Komoditas yang diusahakan adalah tanaman padi dengara rata-rata penguasaan lahan adalah 31 Are dengan kisaran luas antara 10 are sampai dengan 45 are. Usahatani ini dilakukan bersama-sama dengan anggota rumahtangga yang lain baik anak maupun suami. Hanya saja petani perempuan yang lebih banyak melakukan kegiatan usahatani dibandingkan dengan suaminya. Karena suaminya telah memiliki pekerjaan sampingan seperti tukang. Pekerjaan ini dilakukan oleh perempuan karena ini merupakan pekerjaan utamanya. Rata rata besarnya modal pnjaaman untuk usahataninya ini adalah Rp. 2.200.000,- yang sepenuhnya dipergunakan untuk kegiatan usahataninya. Adapun bunga pinjamnannya adalah dua persen yang dikredit sebangak 10 kali. Modal ini dipergunakan untuk membeli sarana produksi berupa bibit, obatobatan/ pestisida seperti confidor dan virtako, pupuk seperti pupuk urea, SP 36, KCL dan juga untuk upah menyewa traktor.

Bila dilihat dari umur petani perempuan yang profesinya sebagai petani adalah relative lebih tinggi dibandingkan dengan usaha yang lainnya yaitu 53.2 tahun dengan kisaan umur 44-69 tahun yang tergolong produktif dan sampai diluar produktif. Begitu pula dengan pendidikkannya relative lebih rendah jika dibandingkan dengan perempuan yang profesinya 
sebagai pedagang yaitu dengan lama pendidikkakan rata rata 7,2 tahun yang setingkat dengan SMP. Rataan tangguangan atau beban keluarganya sebesar 4,4 orang, hal ini menyebabkan petani perempuan harus memiliki usaha sampingan selain selain sebagai petani yaitu untuk membantu menambah pendapatan rumahtangganya (Tabel 1).

\section{Usaha tukang jahit}

Perempuan yang memiliki pekerjaan utama sebagai tukang jahit hanya satu orang (3\%) dan juga pekerjaan sampingaanya sebagai petani yang berumur 47 tahun dengan tingkat pendidikkan sederajat SMA dengan lama pendidikkan 12 tahun. Jumlah anggota rumahtanganya sebanyak 4 orang yang terdiri atas suami dan dua naknya yang berjenis kelamin laki dan perempuan. Sesuai dengan profesinya sebagai penjahit memerlukan tingkan pengetahuan yang lebih tinggi karena memerlukan ketelitan dan kecermatan yang lebih tinggi dibandingkan dengan profesi yang lainnya sehingga pendidikkannya relative lebih tinggi.

Jumlah pinjamannya adalah Rp. 10.000.000,- dengan bunga dua prosen menetap per tahun dengan jangka pinjamna 24 bulan. Usaha menjahit ini memerlukan modal usaha hingga mencapai sembilan juta dan satu juta dipergubakan untuk kebutuhan kegiatan ritual

\section{Wirausaha}

Wirausaha yang dimaksud disini adalah usaha yang dilakukan dengan mengasilkan suatu produk seperti memproduksi Jaje Begina, memproduksi aneka kue basah, usaha warung dan usaha produksi Ayam Betutu dan usaha jamur yang berjumlah 17\%. Adapun rata rata umur adalah 42,57 dengan rentang umur 37-51 tahun. Lamanya penedidikan yang ditempuh 12 tahun yang setingkat dengan SMA, hal ini menunjukkan perempuan yang berprofesi sebagai wirausaha membutuhkan penddidikan yang relative tinggi dan juga dengan umur yang relatif lebih muda jika dibandingkan profesi yang lannya.

Jumlah pinjaman untuk pengusaha ini adalah relative paling tinggi jka dibandingkan dengan profesi yang lainnya yaitu mencapai Rp.15.528.571,-. Dengan bunga pinjaman dua prosen menurun, dan lama pinjamannya 24 bulan. Profesi ini memerlukan dana yang relative tinggi untuk membangun uasahanya, misalmya pengusaha ayam betutu dan jamur memimjam kredit hingga mencapai Rp. 40.000.000,- semua pinjamannya dipergunakan untuk usaha. Lain lagi halnya dengan wirausaha yang mengelola warung makan meminjam kredit hingga Rp. 50.000.000,-, tapi dana pinjamam ini sebagian besar dimanfaatkan untuk perbaikan rumah hingga mencapai Rp. 40.000.000,- Hal ini terjadi karena warung makannya sudah berjalan sangat baik sehingga pengahsilan dari warung makan yang diusahan ini telah mampu untuk membayar kredit pinjamannya setiap bulan.

\section{Akses Perempuan Dalam Mendapatkan Modal Ekonomi (KUM)}

Menurut kajian yang dilakukan oleh International Finance corporate (IFC) bahwa perempuan memeiliki tingkat pengembalian pinjaman yang cukup baik bahkan lebih baik dibandingkan 
dengan laki-laki. Dikatakan pula bahwa rendahnya jumlah pinjaman yang dsalurkan pada perempuan karena adanya tuntutan angunan yang diperlukan.

Hasil penelitian menunjukan bahwa selama dua tahun terakhir ini di tahun 2016 dan tahun 2017 terjadi peningkatan jumlah peminjam kredit KUM di KUAT subak Guama dengan nilai pinjaman yang meningkat pula. Secara lengkap jumlah peminjam dan besarnya kredit yang disalurkan di Kuat Subak Guama akan disajikan pada Tabel 2.

Tabel 2. Jumlah Peminjam Kredit KUM di KUAT Subak Guama tahun 2016-2017

\begin{tabular}{llllll}
\hline No & Keterangan & $\begin{array}{l}\text { jumlah } \\
\text { peminjam } \\
\text { (orang) }\end{array}$ & $\begin{array}{l}\text { perempuan } \\
(\%)\end{array}$ & $\begin{array}{l}\text { laki -laki } \\
(\%)\end{array}$ & $\begin{array}{l}\text { Jumlah } \\
\text { Pinjaman } \\
(\mathrm{Rp})\end{array}$ \\
\hline 1 & 2016 & 282 & 18 & 82 & 1.645 .336 .729 \\
2 & 2017 & 287 & 21 & 79 & 2.227 .341 .392 \\
\hline
\end{tabular}

Sumber: KUAT Subak Guama, 2018.

Pada Tabel 2 nampak bahwa tejadi peningkatan jumlah peminjam yang relatif rendah hanya1,77 \% baik untuk petani laki laki maupun petani perempuan. Jumlah pinjaman Kredit KUM di Subak Guama dari tahun 2016-2017 mengalami pengingkatan 35,37 \%. Jumlah petani perempuan yang memanfaatkan kredit KUM di Subak Guama lebih rendah jika di bandingkan dengan petani laki-laki baik di tahun 2016 maupun 2017. Ditahun 2016 perempuan hanya 18 $\%$ memanfaatkan dana Kredit KUM, sedangkan laki-laki sangat dominan memanfaakan kredit KUM hingga mencapai 82\%. Namun di Tahun 2017 perempuan mengalami peningkatan dalam memanfaatkan dana kredit KUM di tahun 2016 hanya 18\% sedangkan di tahun 2017 mencapai 21\%, sedangkan petani laki-laki mengalami penurunan dari tahun 2016 adalah $82 \%$ dan di tahun 2017 hanya menjadi $79 \%$.

Hal ini menunjukan bahwa akses perempuan dalam memanfaatkan dana Kredit KUM masih sangat rendah yaitu hanya mencapai 18\% di tahun 2016 dan hanya $21 \%$ di tahun 2018. Dengan demikian akses perempuan dalam mengakses dana kredit KUM untuk dua tahun terakhir hanya mencapai $19,5 \%$. Hal ini menggambarkan bahwa petani perempuan belum memanfaatkan peluang yang ada secara maksimak untuk mengakses kredit KUM yang ada di Subak Guama. Dalam sejarah pendirian KUAT Subak Guama di tahun 2001 bahwa KUM ini khusus diperuntukan pada petani perempuan untuk menunjang usaha suami sebagai petani. Perempuan diharapkan maksimal memanfaatkan dana KUM ini supaya mampu untuk menambah pendapatan rumahtangganya sehingga kesejahteraan petani menjadi meningkat. Kajian selanjutnya perlu dilakukan kenapa petani perempuan mengakses KUM masih rendah.

\section{Tingkat Pendapatan Perempuann Dari Pengelolaan Modal Ekonomi (KUM)}

Petani perempuan yang memanfaatkan kredit KUM di Subak Guama mempunyai variasi usaha yang relative beragam. Usaha yang dikembangkan meliputi sebagai pedagang (57), usaha tani (17), penjahit (3\%) dan wirausaha (23\%). Masing-masing usaha yang dikembangkan memiliki variasi dalam pengelolaanya baik dari struktur biaya maupun struktur penerimannya. Secara 
ringkas akan disajikan pendapatan dari masing-masing usaha yang dikembangkan berdasarkan stuktur biaya dan struktur penerimannya akan disajikan pada Tabel 3 .

Tabel 3. Pendapatan Rata Rata Petani Perempuan Per Tahun Berdasarkan Usaha Yang Dikembangkan Sesuai Dengan Struktur Biaya dan Stuktur Penerimaan, Tahun 2018.

\begin{tabular}{|c|c|c|c|c|c|}
\hline No & Uraian & Usaha Dagang & Usahatani & Usaha jahit & Wirausaha \\
\hline \multirow[t]{4}{*}{1} & Penerimaan & 214.778.117 & 34.749 .000 & $99,600,000$ & $285,750,000$ \\
\hline & $\begin{array}{l}\text { Biaya } \\
\text { a. Variabel }\end{array}$ & 162.900 .000 & 7.929 .780 & 58.680 .000 & 122.794 .200 \\
\hline & b. Tetap & $2.427,552$ & 528.000 & 33 z르 888000 & 5307645.5 .847 .645 \\
\hline & c. Total Biaya & 165.327 .552 & 8.457 .780 & 62.008 .800 & 128.101 .845 \\
\hline 3. & $\begin{array}{l}\text { Pendapatan } \\
\text { dari usaha }\end{array}$ & 49.450 .566 & 26.291 .220 & 37.591 .200 & 157.648 .155 \\
\hline 4 & $\mathrm{R} / \mathrm{C}$ ratio & 4,34 & 4,11 & 1,60 & 2,23 \\
\hline
\end{tabular}

Sumber: Diolah dari Data Primer, 2018

Pada Tabel 3 nampak bahwa pendapatan yang terbesar terdapat pada profesi sebagai wirausaha hingga mencapai 58\% dari total pendapatan (Rp 270,981,141) dari usaha yang dikembangkan oleh petani perempuan namun memiliki nilai RC yang lebih rendah dari profesi sebagai pedagng. Kalau dilihat dari Nilai $\mathrm{R} / \mathrm{C}$ yang diperoleh maka profesi sebagai pedagang memberikan nila $\mathrm{R} / \mathrm{C}$ yang terbesar ini berarti usaha dagang paling baihk dalam pengembalian modalnya. Dan paling layak untuk dikembangkan. Sumbangan pendapatan dari usaha dagang ini hanya mencapai $18 \%$ sedangkan peberimaan dari profesi sebagai penjahit mencapai $14 \%$ dan sebagai petani hanya $9 \%$.

Rata rata pendapatan per tahun dari usaha yang dikembangkan oleh perempuan di Subak Guama dengan memanfaatkan Kredit KUM adalah sebesar Rp 67,745,285.25 dengan kisaran pendapatan Rp 15,847,200 sampai dengan Rp. 275,229.120,- Sedangkan pendapatan total rumahtangga Rp. 125,615,276.5 per tahun. Dengan demikian kontribusi perempuan terhadap pendapatan rumahtangga mencapai $53,93 \%$

\section{SIMPULAN DAN SARAN}

\section{Simpulan}

Melalui pembahasan bab sebelumnya maka dapat ditarik beberapa kesimpulan sebagai berikut. Akses perempuan terhadap modal ekonomi KUM di subak Guama hanya mencapai 20\% dari total peminjan KUM 256 orang. Sedangkan penggunaan kedit KUM ini sebagian besar (63\%) dimanfaatkan untuk usaha. Hanya sebagian kecil (47\%) untuk memenuhi kebutuhan konsumsi. Pendapatan dari usaha yang dikembangkanrata-rata mencapai, Rp 67,745,285.25 - 
per tahun, dengan total pendapatan rumahtangga sebesar Rp. 125,615,276.5 per tahun, dimana kontribusi perempuan terhadap pendapatan rumahtangga mencapai 53,93.

\section{Saran}

Saran yang diajukan dalam penelitian ini ditujukan kepada KUAT subak Guama supaya memberikan peluang yang lebih besar kepada petani perempuan untuk mengakses kredit KUM. Pihak petani perempuan dapat lebih meningkatkan partisipasinya untuk memanfaatkan kredit KUM yang ada di Subak Guama.

\section{UCAPAN TERIMAKASIH}

Ucapan terimaksih yang sedalam dalamnya ditujukan kepada rektor universitas udayana melalui lppm telah memberikan dana penelitian dari sumber dana pnbp unud periode tahun 2018. Ucapan terimaksih jga disampaikan pada semua pihak yang telah membantu sehingga penelitian ini bisa diselesaikan tepat pada waktunya.

\section{DAFTAR PUSTAKA}

Astiti, Ni Wayan Sri. 2012. Ketimpangan Gender Dalam Pengelolaan Subak Guama Di Kecamatan Marga, Tabanan Bali (Disertasi). Denpasar: Program Pascasarjana Universitas Udayana.

BPS Provinsi Bali. 2015. Keadaan Ketenagaan Kerjan Provinsi Bali Tahun 2014. Berita Resmi Statistik Provinsi Bali.

Hasil Survei Angkatan Kerja Nasional (SAKERNAS) tahun 2010.

Karmini, Ni Wayan. 2011.Keterpinggiran Perempuan Hindu Pekerja Hotel Berbintang Lima Di Kawasan Sanur, Denpasar Selatan, Kota Denpasar. Denpasar: Program Pascasarjana, Universitas Udayana.

Mantra, I.B.1993. Bali: Masalah Sosial dan Modernisasi. Denpasar:PT Upada Sastra.

Putra, I Nyoman Darma. 2003. Wanita Bali Tempo Doeloe Perspektif Masa Kini, Penerbit Yayasan Bali Jani, Gianyar. Cetakan I.

Putnam, Robert. 1993. The Prospetous Community: Social Capital and Public Life, The American Prospect, 13 (Spring 1993): 35-42.

Sedana G. 2013. Modal Sosial Dalam Pengembangan Agribisnis Petani Pada Sistem Subak Di Bali (Disertasi). Denpasar: Program Studi Ilmu Pertanian, Program Pascasarjana, Universitas Udayana. 
Sunasri, I Gusti Ayu. 2004. Konflik Peran Perempuan Bali Di Desa Pemecutan Kaja, Kecamatan Denpasar Barat, Kota Denpasar (Tesis). Denpasar: Program Magister Kajian Budaya, Pascasarjana, Universitas Udayana.

Soekartawi ,1993. Resiko Dan Ketidakpastian Dalam Agribisni: Teori Dan Aplikasi . Cetakan Pertama Jakarta Grafindo.

Soekartawi, 1995. Analisis Usahatani. Jakarta UI-Press. 